\title{
Ageing Assessment of Dielectric Vegetable Oils
}

\author{
Juan Carcedo, Inmaculada Fernández, Alfredo Ortiz, Fernando Delgado, Carlos \\ J. Renedo, Carmen Pesquera*
}

Electrical and Energy Engineering Department

* Chemical and Processes and Resource Engineering Department

School of Industrial and Telecommunications Engineering, University of Cantabria, Avda. Los Castros, s/n. Santander, Spain

Key words: vegetable ester, mineral oil, paper, aging, power transformers

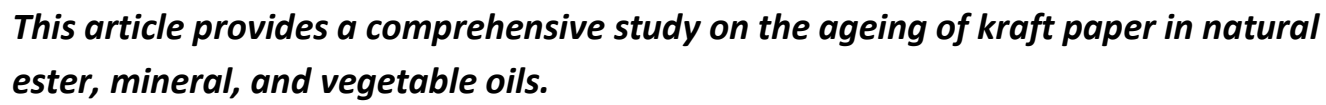

\section{Introduction}

The combination of a dielectric solid (paper) and a dielectric liquid (mineral, vegetable or silicone) is the most commonly used insulation system in power transformers because of the favourable dielectric properties of these insulations and the high heat capacity of the oil, which allows for cooling. It is known that temperature is the main parameter in determining the ageing of these insulations and, therefore, the lifetime of a power transformer [1], [2].

Currently, for reasons of safety and sustainability, the current trend is the use of vegetable oils, whose behaviour as a coolant and dielectric fluid is different from traditional mineral oils. Therefore, knowing the behaviour of the oil-paper insulation system, its evolution over time, the location in the transformer, and the maximum temperature reached, is critical from the point of view of managing electrical power infrastructures [3].

Early attempts to replace traditional mineral oil with alternative fluids in power transformers were performed to reduce the risk of fire because mineral oils are characterized, among other properties, by a low flashpoint. H. Borsi [4] published an article in 1990 in which a synthetic ester based oil (MIDEL ${ }^{\circledR} 7131$ ) was studied as an alternative to mineral oil from the standpoint of eliminating the possibility of PCBs and, therefore, achieving safer operation conditions. Subsequently, concern for the environment and the biodegradability of the liquids used as dielectrics was a bonus reason for the study and development of vegetable oils in power transformers. There have been many studies conducted and published on the use of dielectric fluids with respect to the environment [5]-[7], and several oils have been patented for this purpose [8],[9]. A complete review of alternative fluids for power transformers can be seen in [10].

In recent years, most studies on the use of vegetable oils as a dielectric in power transformers have focused on either the evolution of their dielectric properties over time [11] -[14] or their influence on the ageing of impregnated paper in these oils [15] - [20]. In 2013, Coulibaly et al. [19] aged paper and a high density transformer board at $130{ }^{\circ} \mathrm{C}$ up to 1128 hours in sealed vessels in the presence of mineral oil, natural ester and synthetic ester. They then measured the evolution of the moisture content of oils and the paper and pressboard, the $\mathrm{CO}$ and $\mathrm{CO}_{2}$ gas production, the oil acidity and dielectric dissipation factor, the furanic compounds (2-FAL) production and the degree of polymerization (DP) of both paper and pressboard. 
More recently, in 2014, Singha et al. [20] compared the ageing characteristics between a high oleic natural ester dielectric fluid and mineral oil on an accelerated single-temperature thermal ageing experiment at $150{ }^{\circ} \mathrm{C}$ for a period of 3000 hours, measuring and analysing the physical (colour, viscosity, moisture content and acidity) and dielectric (dielectric constant, power factor and AC breakdown voltage) properties of both the oils at different intervals.

In this article, mineral oil, two different vegetable oils and kraft paper ageing are analysed after having been thermally accelerated and aged at 110,130 and $150^{\circ} \mathrm{C}$. Physical, dielectric properties, moisture content, acidity, dissolved gases, loss factor and DC resistivity for the different types of oil and the moisture content and degree of polymerization for kraft paper has been studied. Therefore, this is a comprehensive study on the ageing of vegetable oils compared to mineral oil under different working conditions.

\section{Materials and methods}

Because the aim of this work is to study vegetable oil/paper insulation ageing compared to the corresponding mineral oil/paper insulation, what has been experimentally realized was accelerated thermal ageing at three different temperatures (110, 130 and $150^{\circ} \mathrm{C}$ ) of the dielectric system based on three different oils (two vegetable oils and mineral oil). Then, different tests have been performed to study the state of the paper and oil. This range of temperatures allows us to perform an accelerated test without the risk of side effects due to pyrolysis or carbonization.

The sample preparation process is performed as follows. First, strips of kraft paper (260 x $15 \mathrm{~mm}$ ) are introduced in three steel vessels in which a vacuum is created to remove most of the moisture. Subsequently, the vessels are filled with nitrogen for which hygroscopicity helps remove moisture from the paper. Under these conditions, the vessels are placed in an oven at $100{ }^{\circ} \mathrm{C}$ for a period of 24 hours, so that the paper finally reaches a moisture content of approximately $0.5 \%$. Finally, the vessels are opened, and different oil is poured into each one and the vacuum and nitrogen filling processes are repeated. Once the samples are prepared, they are then aged in an oven at 110,130 and $150^{\circ} \mathrm{C}$.

Table 1. Physicochemical and dielectric properties with applicable standards.

\begin{tabular}{|c|c|}
\hline Property & Standard \\
\hline \multicolumn{2}{|c|}{ Physicochemical properties } \\
\hline Degree of polymerization (paper) & $\begin{array}{l}\text { ASTM D } 4243 \\
\text { IEC } 60450\end{array}$ \\
\hline Moisture content (paper) & IEC 60814 \\
\hline Moisture content (oil) & IEC 60814 \\
\hline Acidity (oil) & $\begin{array}{l}\text { ASTM D } 664 \\
\text { IEC } 62021\end{array}$ \\
\hline Dissolved gasses (oil) & IEC 60599 \\
\hline \multicolumn{2}{|c|}{ Dielectric properties } \\
\hline Dielectric dissipation factor (oil) & IEC 60247 \\
\hline DC resistivity (oil) & IEC 60247 \\
\hline
\end{tabular}

Depending on the temperature, the ageing time will be different in each case. During the ageing time and at different intervals, paper and oil samples are taken and tested. Because the ageing rate is expected to increase as temperature rises, sampling is 
performed at $150^{\circ} \mathrm{C}$ more frequently than at $110^{\circ} \mathrm{C}$. Moreover, degradation is more pronounced at the beginning of the ageing process, so the latest samples are taken at longer time intervals.

For the three oils, the parameters of moisture content, acidity, dissolved gases, loss factor and DC resistivity were studied. The moisture content and the degree of polymerization of the Kraft paper were analysed. Table 1 summarizes the studied parameters and the standards that were applied.

Table 2 shows some of the initial properties of the three oils studied. Table 3 contains some remarkable features of the Kraft paper used in these experiments. In all cases, the data have been provided by manufacturers.

Table 2. Properties of analysed oils;mineral oil (MO), vegetable oil type 1 (VO1) and vegetable oil type 2 (VO2).

\begin{tabular}{|l|l|l|l|l|l|}
\hline \multicolumn{1}{|c|}{ Property } & \multicolumn{1}{c|}{ Units } & \multicolumn{1}{c|}{ Standard } & \multicolumn{1}{c|}{ MO } & \multicolumn{1}{c|}{ VO1 } & \multicolumn{1}{c|}{ VO2 } \\
\hline $\begin{array}{l}\text { Viscosity, } \\
40^{\circ} \mathrm{C}\end{array}$ & $\mathrm{mm}^{2} / \mathrm{s}$ & $\begin{array}{l}\text { ISO 3104 } \\
\text { ASTM D 445 }\end{array}$ & 7.6 & 37 & 39.2 \\
\hline Density, 20 ${ }^{\circ} \mathrm{C}$ & $\mathrm{kg} / \mathrm{dm}^{3}$ & $\begin{array}{l}\text { ISO 12185 } \\
\text { ISO 3675 } \\
\text { ASTM D 1298 }\end{array}$ & 0.877 & 0.92 & 0.9128 \\
\hline $\begin{array}{l}\text { Breakdown } \\
\text { voltage } \\
(2.5 \mathrm{~mm})\end{array}$ & $\mathrm{kV}$ & IEC 60156 & $40-60$ & $>75$ & 81 \\
\hline Acidity & $\mathrm{mgKOH/g}$ & $\begin{array}{l}\text { IEC 62021 } \\
\text { ASTM D 974 }\end{array}$ & 0.01 & $<0.05$ & 0.05 \\
\hline $\begin{array}{l}\text { Tan delta } \\
\left(90^{\circ} \mathrm{C} \text { and } 50\right. \\
\text { Hz) }\end{array}$ & IEC 60247 & 0.001 & $<0.005$ & 0.0134 \\
\hline Flash point & ${ }^{\circ} \mathrm{C}$ & $\begin{array}{l}\text { ISO 2719 } \\
\text { ASTM D 92 }\end{array}$ & 144 & 327 & 332 \\
\hline $\begin{array}{l}\text { Moisture } \\
\text { content }\end{array}$ & $\mathrm{mg} / \mathrm{kg}$ & IEC 60814 & $<20$ & 50 & 100 \\
\hline
\end{tabular}

Table 3. Properties of analysed Kraft paper.

\begin{tabular}{|c|c|c|c|}
\hline Property & Units & Standard & Value \\
\hline Thickness & $\mathrm{mm}$ & \multirow{4}{*}{ IEC 554} & 0.075 \\
\hline Grammage & $\mathrm{g} / \mathrm{mm}$ & & 61 \\
\hline Apparent density & $\mathrm{g} / \mathrm{cm}^{3}$ & & 0.8 \\
\hline Electric strength in air & $\mathrm{kV} / \mathrm{mm}$ & & 7 \\
\hline
\end{tabular}

\section{Fundamentals}

Natural ester consists of glycerol and fatty acids, which are known as triglycerides, and can be subjected to either oxidation or hydrolysis because of the structure of its molecule. In natural ester, double $\mathrm{C}$-C valence bonds could promote oxidation, while single $\mathrm{COOH}$ valence bonds could introduce hydrolysis.

According to previous findings [21], oxidation starts with the induction period where the carbon atom in natural ester reacts with oxygen to create a free radical from the loss of the hydrogen atom. The free radical reacts with oxygen and creates peroxide radicals. The propagation period starts once the peroxide radicals decompose to create hydroperoxide. The final by-products of this reaction include aldehydes and ketones. 
Hydrolysis of natural ester can take place in three stages where all of them are reversible. The first stage is the creation of diglyceride formed by a triglyceride interaction with water. Once the diglyceride reacts with water, it will create monoglyceride, which will form into glycerol as a final reaction product. During all stages, fatty acid will be created as a by-product.

\section{Results and discussion}

The ageing tests were done at 110,130 and $150^{\circ} \mathrm{C}$ using mineral oil (MO), natural ester vegetable oil type 1 (VO1) and natural ester type 2 (VO2).

\section{Evolution of degree of polymerization of Kraft paper}

Figure 1 shows the effect of ageing on the degree of polymerization of paper impregnated in MO, VO1 and VO2 at the three temperatures. As previously determined [22], the degree of polymerization decreases with time, where the fall is more pronounced at the beginning of the process and at higher temperatures.

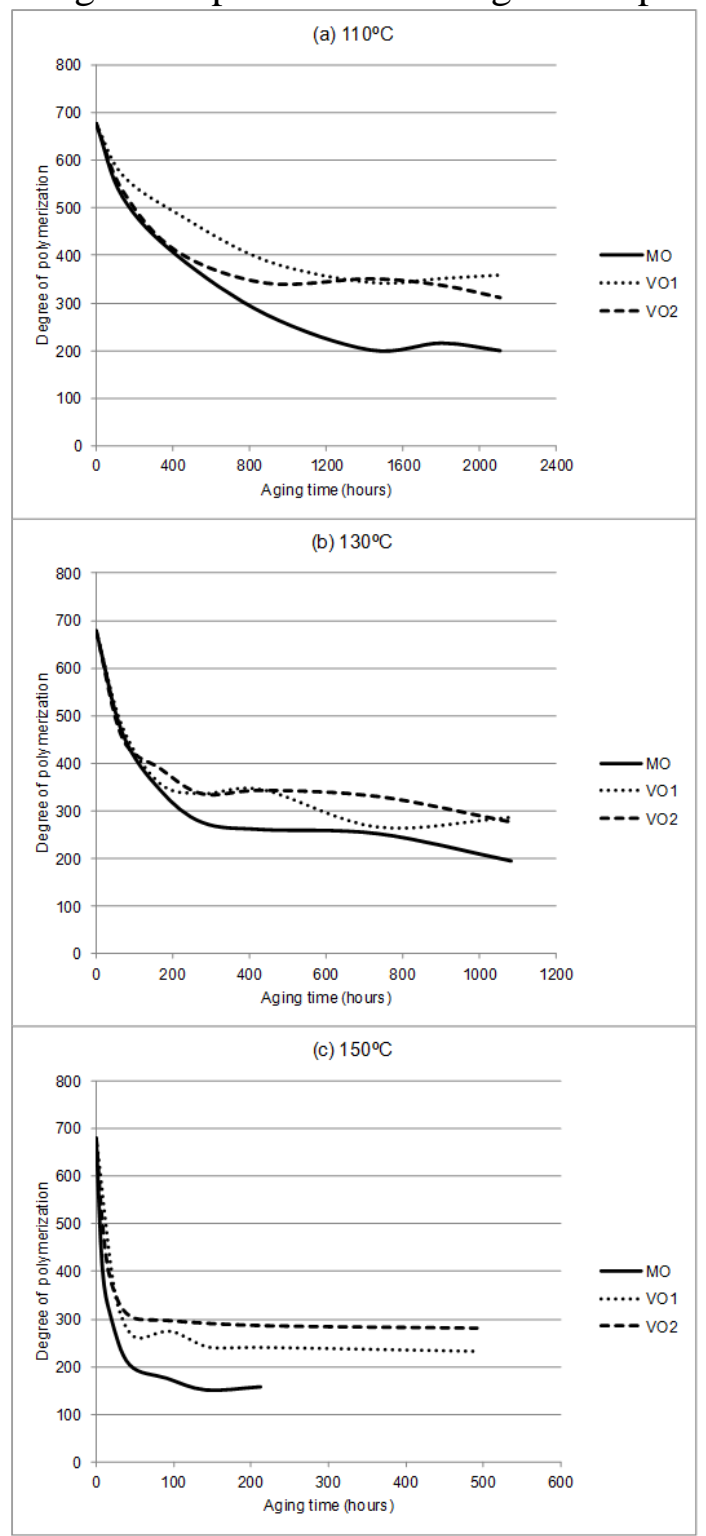

Figure 1. Effect of aging on degree of polymerization of Kraft paper; (a) $110^{\circ} \mathrm{C}$, (b) $130^{\circ} \mathrm{C}$, and (c) $150^{\circ} \mathrm{C}$. 
For example, after ageing for 212 hours at $150^{\circ} \mathrm{C}$, the DP of Kraft paper in mineral oil is reduced by $77 \%$ to 158 (baseline DP0 =678), whereas after aging for 2107 hours at $110^{\circ} \mathrm{C}$ the DP is reduced by $71 \%$. However, Kraft paper aged in oil at 110 and $130{ }^{\circ} \mathrm{C}$ shows a DP nearly 200 at which point there is no guarantee that the transformer can withstand the stresses produced under extreme conditions and is considerably greater than that experienced by the other oils.

To assess which vegetable oils provide better results, at first, VO1 has a final DP value of 360 at $110^{\circ} \mathrm{C}$, which is $16 \%$ higher than in $\mathrm{VO} 2$. When tested at $130^{\circ} \mathrm{C}$, this percentage drops by only $4 \%$.

As shown in Figure 1 , at $130^{\circ} \mathrm{C}$, the rate of reduction in DP is nearly twice than at $110^{\circ} \mathrm{C}$. The temperature effect is more pronounced in mineral oil, which confirms that vegetable oils promote a better conservation of the Kraft paper, in terms of DP. In this case, the final DP value obtained in VO2 is $21 \%$ higher than that obtained under the same conditions with VO1.

\section{Evolution of moisture content of Kraft paper}

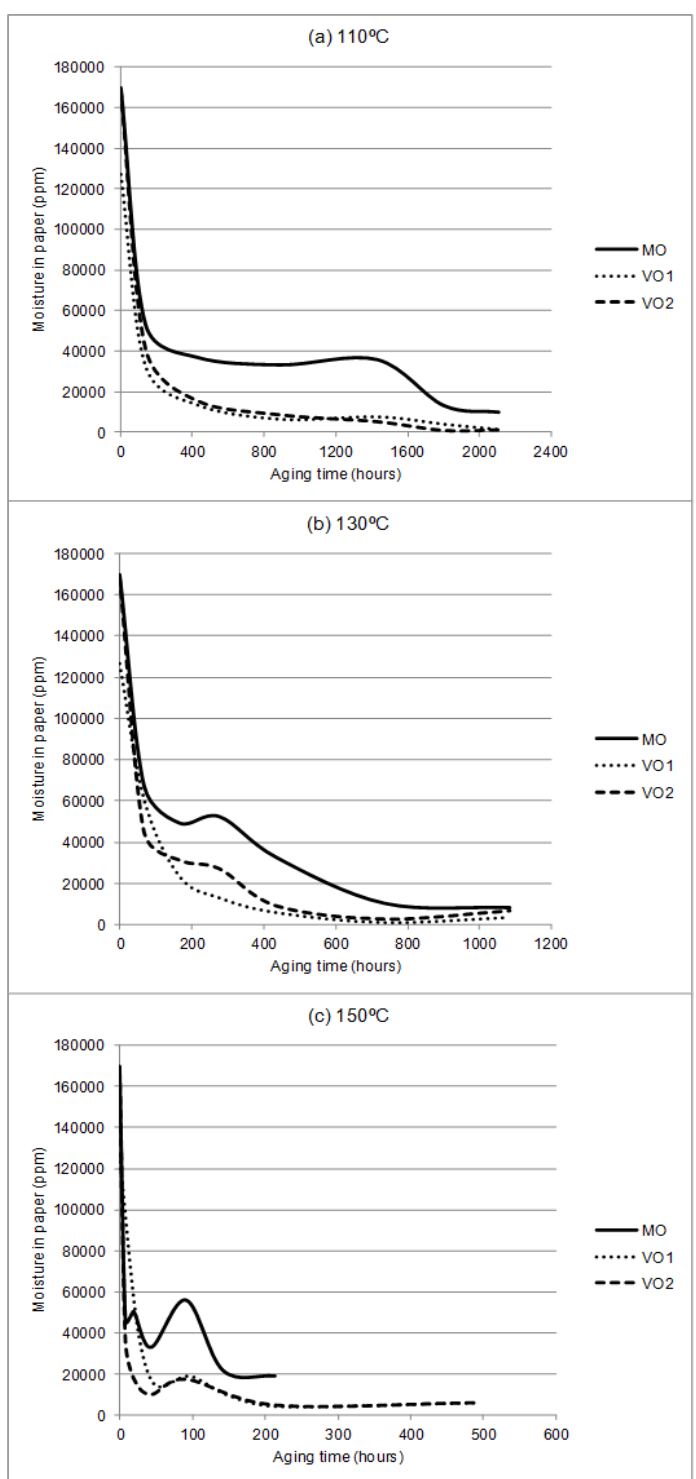

Figure 2. Effect of aging on moisture content of Kraft paper; (a) $110^{\circ} \mathrm{C}$, (b) $130^{\circ} \mathrm{C}$, and (c) $150^{\circ} \mathrm{C}$. 
Moisture content in Kraft paper is one of the most important aspects of power transformer assessment, and its presence is detrimental to insulation properties. The dielectric strength is reduced and as the cellulose ages, gas bubbles are formed at high temperatures. Moisture is also a byproduct of the ageing process.

Figure 2 shows that at the three test temperatures, Kraft paper in mineral oil has the highest moisture content during ageing. This higher moisture content matches the higher degradation experienced by the paper from the viewpoint of the DP. As described in the next section, vegetable oils absorb more moisture such that the paper has a lower water content and, therefore, its degradation is slower than if it were impregnated with mineral oil.

\section{Evolution of moisture content of oil}

Moisture in transformer oil can originate from the atmospheric air or can be a result of the degradation of the insulating materials. For relatively low water content, water remains in solution and does not change the appearance of the oil.

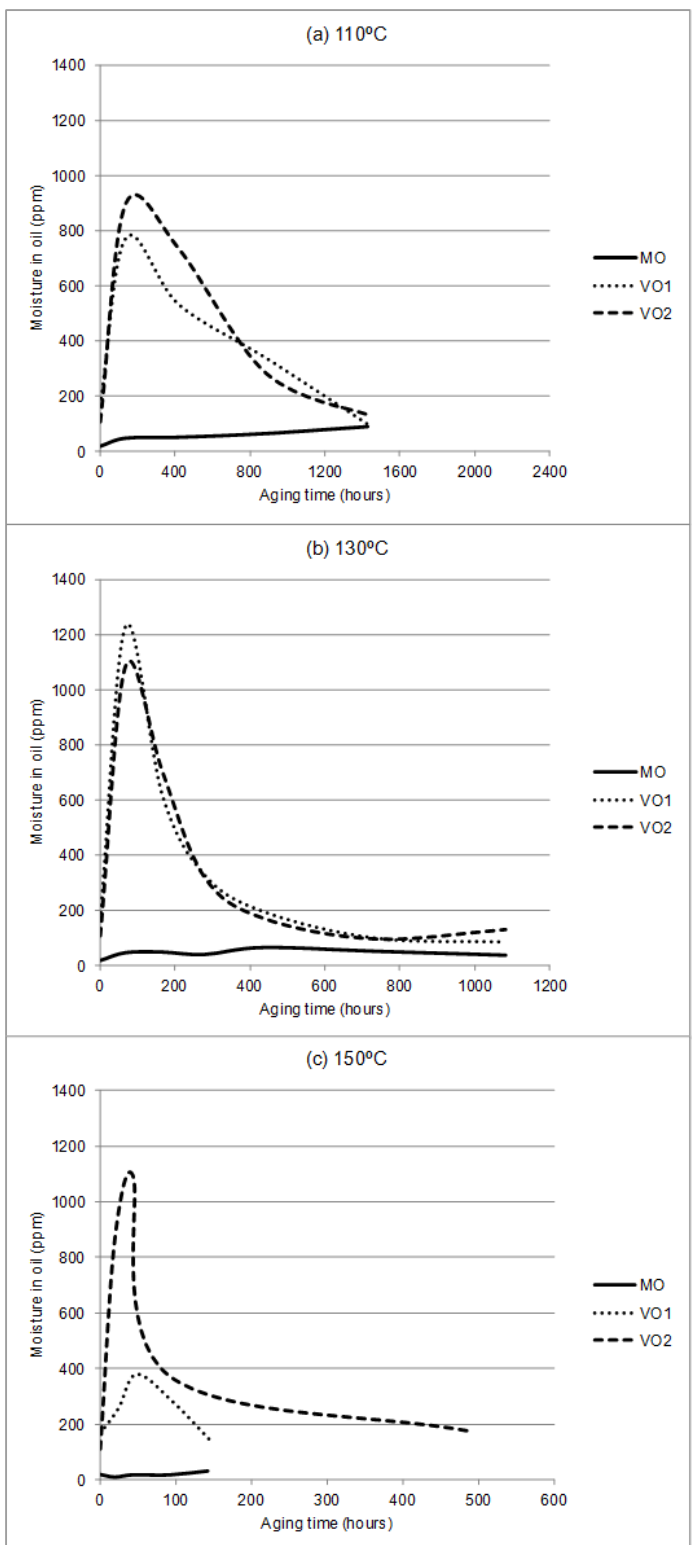

Figure 3. Effect of aging on moisture content of oil; (a) $110^{\circ} \mathrm{C}$, (b) $130^{\circ} \mathrm{C}$, and (c) $150^{\circ} \mathrm{C}$. 
However, when the water content exceeds a certain level, reaching saturation, water cannot remain in solution, and free water appears as turbidity or droplets, causing a decrease in the dielectric strength and resistivity, and an increased dielectric dissipation factor. Moreover, high free water content in oil accelerates the chemical degradation of Kraft paper.

As evident in Figure 3, in terms of the moisture content of oil, mineral oil has excellent results at all times and is far below those obtained in both vegetable oils. At high temperatures, vegetables oils can produce hydrolysis by absorbing water from the paper and, thus, reducing ageing of the paper.

\section{Evolution of acidity}

The acidity of the oil is a measure of the acidic contaminants in the oil. The acidity of used oil is caused by the formation of acid oxidation products. Acids and other oxidation products, along with water and solid contaminants, will affect the dielectric properties of the oil.

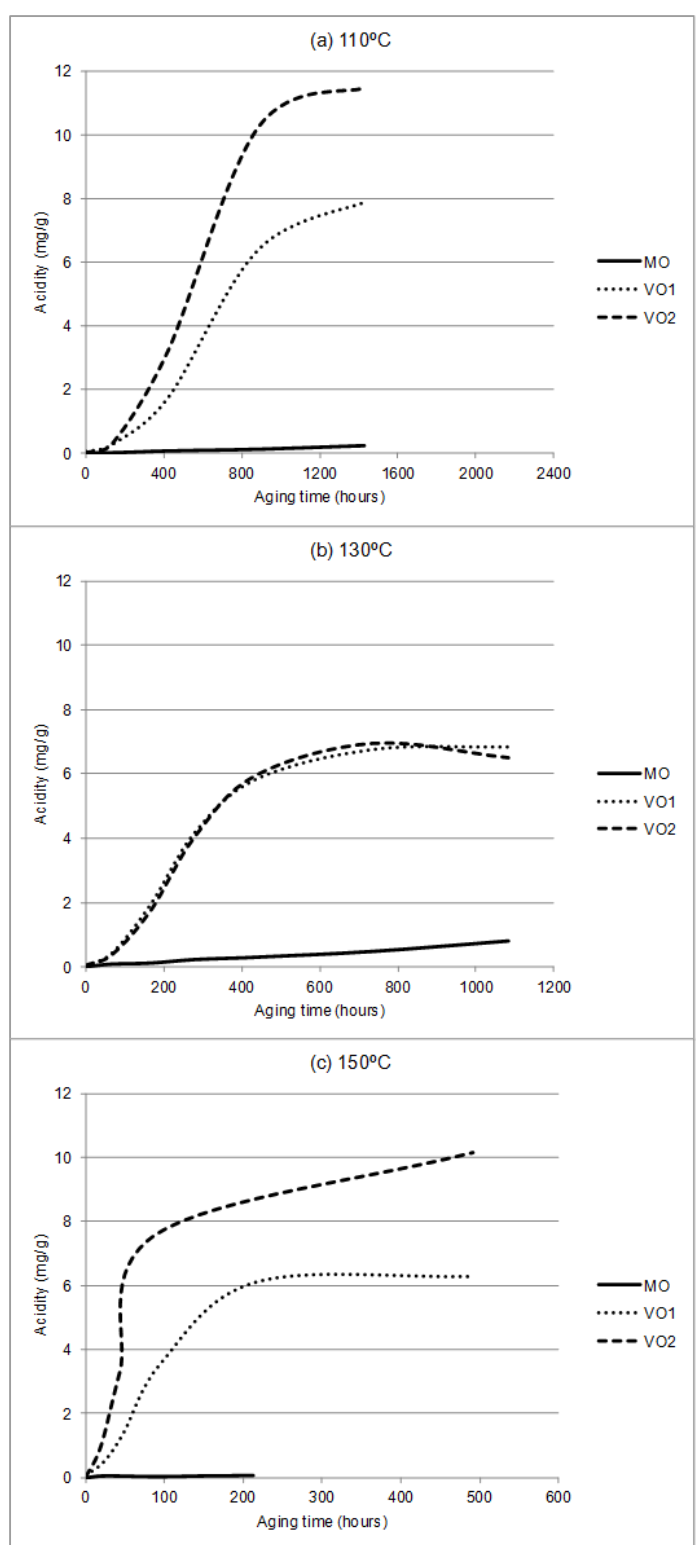

Figure 4. Effect of aging on acidity of oil; (a) $110^{\circ} \mathrm{C}$, (b) $130^{\circ} \mathrm{C}$, and (c) $150^{\circ} \mathrm{C}$. 
Acids have an impact on the degradation of cellulosic materials and may also be responsible for the corrosion of metal parts of the transformer. The rate of increase in the acidity of oil is a good indicator of the rate of ageing.

Figure 4 shows the evolution in the acidity of the tested oils at the three tested temperatures. At these temperatures, mineral oil has lower acidity during the ageing process. The increase in acidity experienced by vegetable oils is very pronounced at first, tending to stabilize after one-half of the ageing period.

\section{Evolution of dissolved gases}

According to IEC 60599 (Table 1), the ratio [CO $\mathrm{CO}_{2}$ / [CO] (square bracket means concentration) can be considered as an indicator of cellulose degradation. Figure 5 shows the evolution of this ratio for the three oils at the three test temperatures. It can be observed that this ratio is higher for mineral oil than for the vegetable oils, which is also confirmed in Figure 1, and has been previously reported [23], [24].

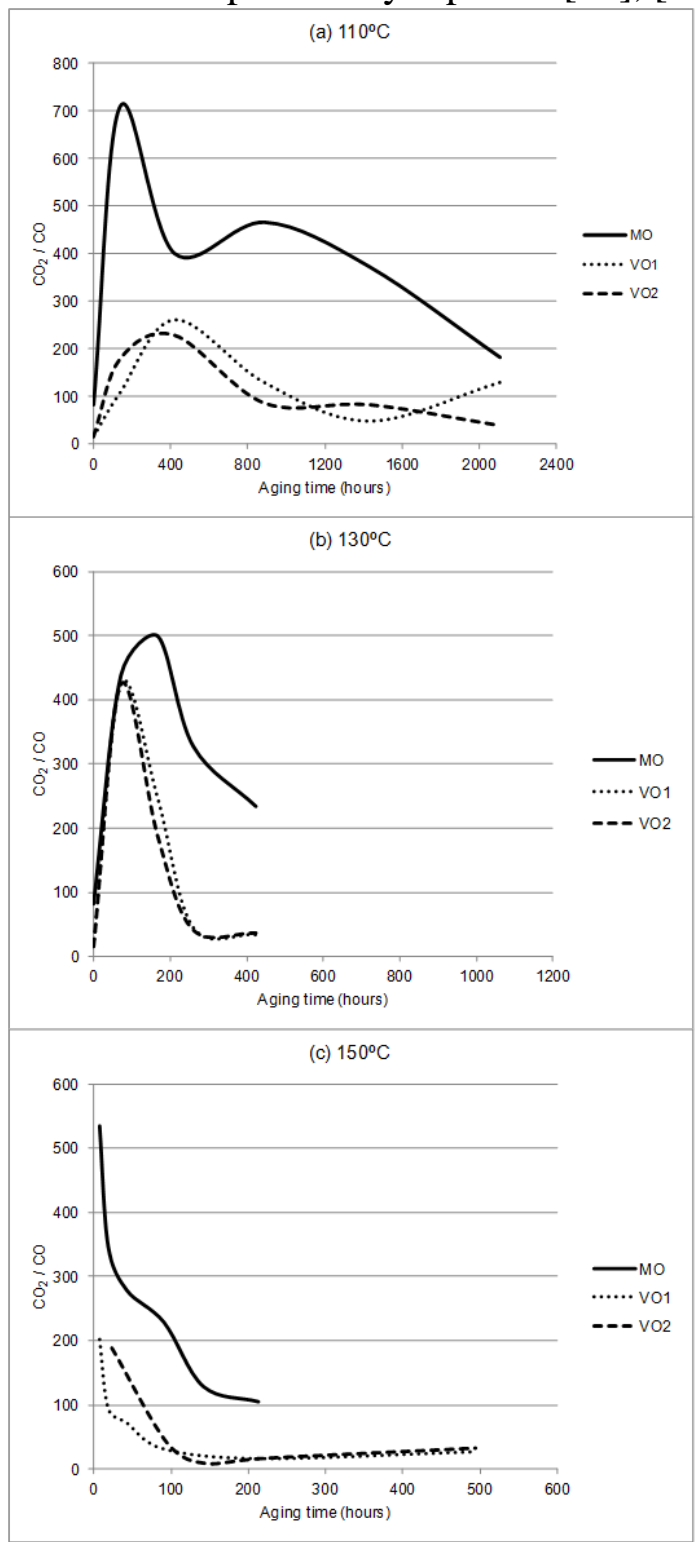

Figure 5. Effect of aging on the ratio $\left[\mathrm{CO}_{2}\right] /[\mathrm{CO}]$; (a) $110^{\circ} \mathrm{C}$, (b) $130^{\circ} \mathrm{C}$, and (c) $150^{\circ} \mathrm{C}$. 


\section{Evolution of dissipation factor and $D C$ resistivity}

A measurement of the dissipation factor (tan delta) allows us to determine the condition of the insulation. Figure 6 shows the evolution of tan delta for the three oils at the three test temperatures. Clearly, the vegetable oils show higher tan delta than for the mineral oil. Therefore, in this aspect, mineral oil presents the best dielectric properties at all temperatures.

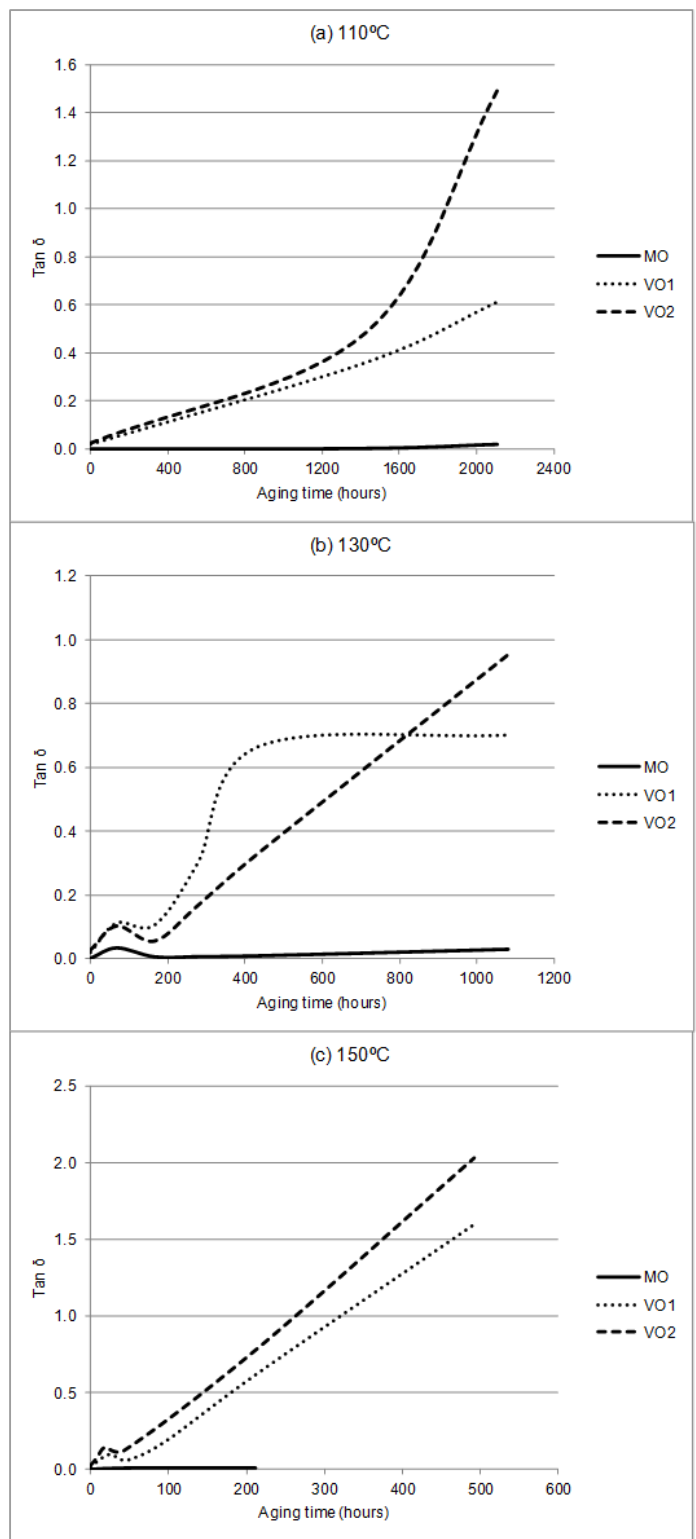

Figure 6. Effect of aging on dissipation factor; (a) $110^{\circ} \mathrm{C}$, (b) $130^{\circ} \mathrm{C}$, and (c) $150^{\circ} \mathrm{C}$.

A high tan delta implies a low resistivity so this property was also measured at both polarities. As both show similar results, only the positive polarity result is shown in Figure 7. 


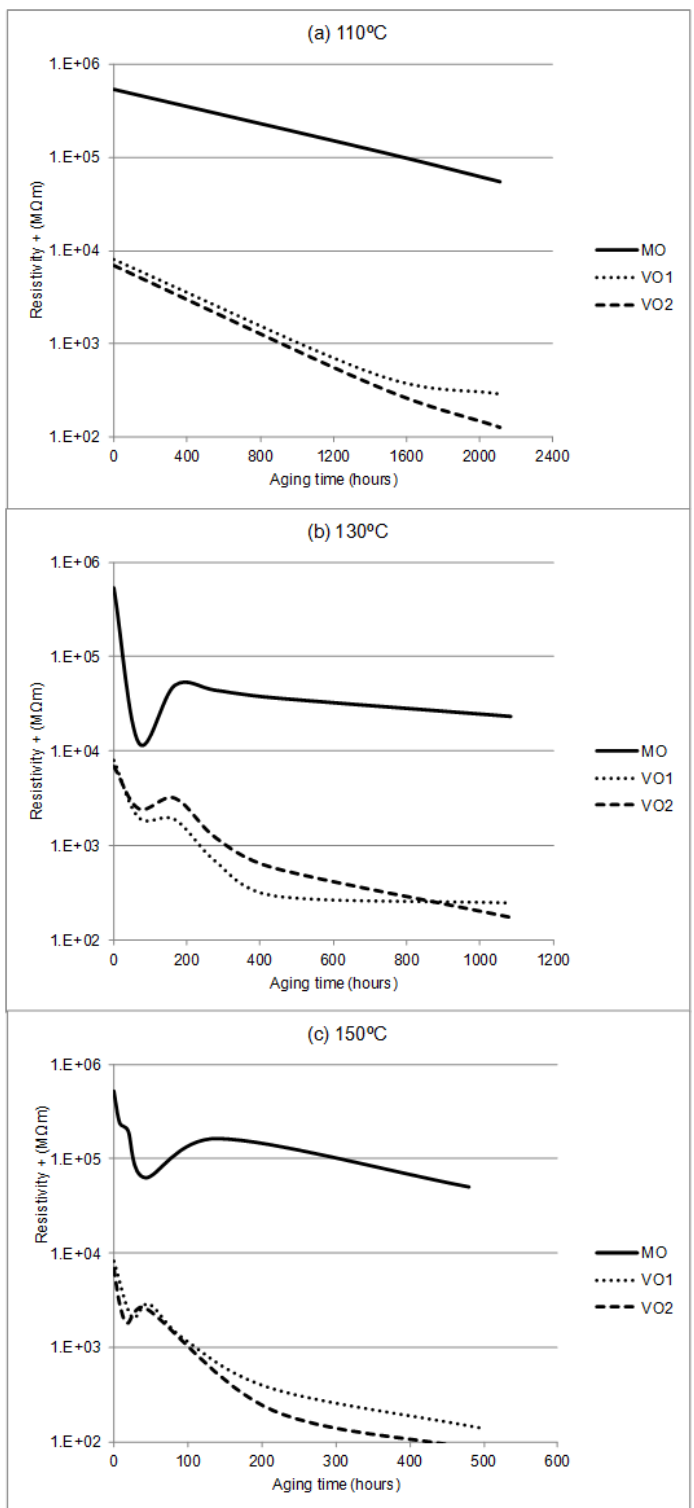

Figure 7. Effect of aging on resistivity for +ve polarity; (a) $110^{\circ} \mathrm{C}$, (b) $130^{\circ} \mathrm{C}$, and (c) $150^{\circ} \mathrm{C}$.

\section{Conclusions}

In this article, we have studied the behaviour of various insulating oils used as dielectric liquids to determine whether vegetable oils, in this case, two types of natural ester-based oils, are a real solution for replacing mineral oils currently used in most electric power transformers.

Through laboratory testing and a subsequent analysis of the results, a series of conclusions were obtained, which seek to confirm that these vegetable oils can perfectly fulfil the role intended. Experimental results show that the degree of polymerization of mineral oil impregnated paper is the lowest for all three temperatures tested $(110,130$ and $150^{\circ} \mathrm{C}$ ), which means further degradation of the dielectric paper. Vegetable esters possess similar behaviours. However, as the temperature of the tests increases, vegetable ester 2 gives slightly better results.

The moisture content in mineral oil impregnated paper is higher than in any of the vegetable oils, which causes greater ageing of the paper. Regarding moisture content in oil, vegetable ester-based oils have higher values because they are able to 
absorb more moisture from the paper by the effect of hydrolysis, as described in [18]. Therefore, mineral oil has worse results compared with the natural ester-based oils considered in this study.

Acidity determines the degree of contamination in the dielectric oil, and as shown above, the mineral oil has lower values compared with the two vegetable oils tested.

The insulating oil tester allowed us to determine the dielectric dissipation factor (tan delta) and the DC resistivity of oils. Mineral oil has the lowest values for the dielectric dissipation factor, which is linked to good results with respect to the resistivity. This indicates that regarding its dielectric behaviour, this oil is maintained in good condition over time.

The lifetime of a transformer insulation system (paper-oil) is significantly affected by temperature, water content and oxygen. That is, these three variables affect the rate of degradation. However, in this case, only the effect of temperature has been considered, so it would be necessary to obtain additional data under different ageing conditions to allow kinetic models to incorporate the degradation accelerating effect variables in the presence of oxygen and moisture.

Finally, it should be mentioned that this working group is researching the role of vegetable oil as a coolant in power transformers to define, through finite element analysis, the proper geometries of coils and shells from the viewpoint of hot spot locations and their temperature. In this regard, the results reported in this paper are particularly useful and relevant.

\section{References}

[1] C. Krause. "Power transformer insulation-history, technology and design”, IEEE Trans. Dielectr. Elect. Insul., vol. 19, no. xy, pp. 1941-1947, 2012.

[2] N. Lelekakis, W. Guo, D. Martin, J. Wijaya, D. Susa. "A field study of aging in paper-oil insulation systems”, IEEE Electr. Insul. Mag., vol. 28, no. xy, pp. 12-19, 2012.

[3] P.S. Georgilakis, "Spotlight on modern transformer design”, London, U.K.: Springer, 2009.

[4] H. Borsi, "Ester fluid Midel 7131 as PCB-substitute for distribution transformers", in 10th International Conference on Conduction and Breakdown in Dielectric Liquids, Grenoble, France, pp. 514-518, Sept. 1990.

[5] T. Oommen, C. Claiborne, J. Mullen, "Biodegradable electrical insulation fluids”, in 2005 IEEE International Conference on Dielectric Liquids, Coimbra, Portugal, pp. 465468, Jun. 2005.

[6] D. Abeysundara, C. Weerakoon, J. Lucas, K. Gunatunga, K. Obadage, “Coconut oil as an alternative to transformer oil”, in ERU Symposium, pp. 1-11, Nov. 2001.

[7] J. Lucas, D. Abeysundara, C. Weerakoon, K. Perera, K. Obadage, K. Gunatunga, "Coconut oil insulated distribution transformer", in the $8^{\text {th }}$ Annual Conference of the IEE, Sri Lanka, Sept. 2001.

[8] G.S. Cannon, L.A. Honary. "Soybean based transformer oil and transmission line fluid”, US Patent 6159913 A, Dec. 2000.

[9] D.W. Sundin. "Vegetable seed oil insulating fluid”, US Patent 6280659, Aug. 2001.

[10] I. Fernández, A. Ortiz, F. Delgado, C. Renedo, S. Pérez. "Comparative evaluation of alternative fluids for power transformers”, Electric Power Systems Research, vol. 98, pp. 58-69, 2013. 
[11] Y. Bertrand, L.C. Hoang, "Vegetal oils as substitute for mineral oils”, Proceedings of the 7th International Conference on Properties and Applications of Dielectric Materials, Nagoya, Japan, vol. 2, pp 491-494, Jun. 2003.

[12] H. Borsi, E. Gockenbach, "Properties of ester liquid midel 7131 as an alternative liquid to mineral oil for transformers", in 2005 IEEE International Conference on Dielectric Liquids, Coimbra, Portugal, pp. 377-380. Jun. 2005.

[13] C.T. Duy, O. Lesaint, N. Bonifaci, A. Denat, Y. Bertrand, "High voltage breakdown and pre-breakdown properties in rape-seed insulating oil”, in Annual Report - Conference on Electrical Insulation and Dielectric Phenomena, Vancouver, Canada, pp. 623-626, Oct. 2007.

[14] J. Li, S. Grzybowski, Y. Sun, X. Chen, "Dielectric properties of rapeseed oil paper insulation”, in Annual Report - Conference on Electrical Insulation and Dielectric Phenomena, Vancouver, Canada, pp. 500-503, Oct. 2007.

[15] C. McShane, K. Rapp, J. Corkran, G. Gauger, J. Luksich, “Aging of Kraft paper in natural ester dielectric fluid", in Proceedings of 2002 IEEE $14^{\text {th }}$ International Conference on Dielectric Liquids, Graz, Austria, pp. 173-177, Jul. 2002.

[16] K.J. Rapp, C.P. McShane, J. Luksich, "Interaction mechanisms of natural ester dielectric fluid and Kraft paper”, in 2005 IEEE International Conference on Dielectric Liquids, Coimbra, Portugal, pp. 393-396. Jun. 2005.

[17] M.A. Martins. "Vegetable oils, an alternative to mineral oil for power transformersexperimental study of paper aging in vegetable oil versus mineral oil”, IEEE Electrical Insulation Magazine, vol. 26, pp. 7-13, 2010.

[18] L. Yang, R. Liao, S. Caixin, M. Zhu. "Influence of vegetable oil on the thermal aging of transformer paper and its mechanism”, IEEE Transactions on Dielectrics and Electrical Insulation, vol. 18, pp. 692-700, 2011.

[19] M. Coulibaly, C. Perrier, M. Marugan, A. Beroual. “Aging behavior of cellulosic materials in presence of mineral oil and ester liquids under various conditions", IEEE Transactions on Dielectrics and Electrical Insulation, vol. 20, pp. 1971-1976, 2013.

[20] S. Singha, R. Asano, G. Frimpong, C.C. Claiborne, D. Cherry. "Comparative aging characteristics between a high oleic natural ester dielectric liquid and mineral oil”, IEEE Transactions on Dielectrics and Electrical Insulation, vol. 21, pp. 149-158, 2014.

[21] H.M. Wilhelm, L. Tulio, R. Jasinski, G. Almeida. "Aging markers for in-service natural ester-based insulating fluids”, IEEE Transactions on Dielectrics and Electrical Insulation, vol. 18, pp 714-719, 2011.

[22] D. Shroff, A. Stannett, “A review of paper aging in power transformers”, IEE Proceedings C (Generation, Transmission and Distribution), vol. 132, pp. 312-319, 1985.

[23] J.I. Jeong, J.S. An, C.S. Huh. “Accelerated aging effects of mineral and vegetable transformer oils on medium voltage power transformers", IEEE Transactions on Dielectrics and Electrical Insulation, vol. 19, pp. 156-161, 2012.

[24] M.A. Martins, A. Gomes. "Comparative study of the thermal degradation of synthetic and natural esters and mineral oil: effect of oil type in the thermal degradation of insulating kraft paper”, IEEE Electrical Insulation Magazine, vol. 28, pp. 22-28, 2012. 


\begin{tabular}{|c|c|}
\hline & $\begin{array}{l}\text { Juan Carcedo received the M.Sc. degree in Industrial Engineering } \\
\text { in } 2004 \text { and worked as a freelance engineer for ten years and as a } \\
\text { part time Lecturer at the University of Cantabria from } 2009 \text { to } 2014 . \text {. } \\
\text { Currently, he is Assistant Lecturer of the Electrical and Energy } \\
\text { Engineering Department in the School of Industrial Engineering at } \\
\text { the University of Cantabria. His main research topic is the study of } \\
\text { transformer ageing and insulating oils and paper. }\end{array}$ \\
\hline & $\begin{array}{l}\text { Inmaculada Fernández received the M.Sc. degree in Chemical } \\
\text { Engineering in } 2004 \text { and the Ph.D. degree in } 2009 \text { from the } \\
\text { University of Cantabria (UC), Spain. Currently, she is Assistant } \\
\text { Lecturer in the Electrical and Energy Engineering Department at the } \\
\text { University of Cantabria. She has published two chapters in } \\
\text { international books, over } 20 \text { works in national and international } \\
\text { conferences and } 9 \text { papers in journals included in the Journal of } \\
\text { Citation Report. Finally, her main research topic is the energy } \\
\text { saving. }\end{array}$ \\
\hline & $\begin{array}{l}\text { Alfredo Ortiz graduated with a PhD in Electrical Engineer at } \\
\text { University of Cantabria in 2005. He has published six chapters in } \\
\text { international books, over } 50 \text { works in international conferences and } \\
21 \text { papers in journals included in the Journal of Citation Report. He } \\
\text { has acted as reviewer for several international journals included in } \\
\text { the Journal of Citation Report. He belongs to national } \\
\text { (AEN/CTN207/SC14 and AEN/CTN207/SC10) and international } \\
\text { committees (CENELEC/TC14/WG29, IEC60076-20 and } \\
\text { IEC/TC10/WG33) for standardization in the field of power } \\
\text { transformers and alternative dielectric fluids. Currently, he is the } \\
\text { Head of Electrical and Energy Engineering Department at the } \\
\text { University of Cantabria. }\end{array}$ \\
\hline & $\begin{array}{l}\text { Carlos J. Renedo received the M.Sc. degree in Industrial } \\
\text { Engineering in } 1997 \text { and the Ph.D. degree in } 2002 \text { from the } \\
\text { University of Cantabria (UC), Spain. Currently, he is Associate } \\
\text { Professor in the Electrical and Energy Engineering Department at } \\
\text { the University of Cantabria. He has published over } 50 \text { works in } \\
\text { international conferences and } 24 \text { papers in journals included in the } \\
\text { Journal of Citation Report. Finally, his main research topic is the } \\
\text { energy saving. }\end{array}$ \\
\hline & $\begin{array}{l}\text { Fernando Delgado received the M.Sc. degree in Industrial } \\
\text { Engineering in } 1998 \text { and the Ph.D. degree in } 2011 \text { from the } \\
\text { University of Cantabria (UC), Spain. Currently, he is Associate } \\
\text { Professor in the Electrical and Energy Engineering Department at } \\
\text { the University of Cantabria. He has published over } 25 \text { works in } \\
\text { international conferences and } 13 \text { papers in journals included in the } \\
\text { Journal of Citation Report. Finally, his main research topic is } \\
\text { currently the study of the alternative dielectric liquids in power } \\
\text { transformers. }\end{array}$ \\
\hline
\end{tabular}




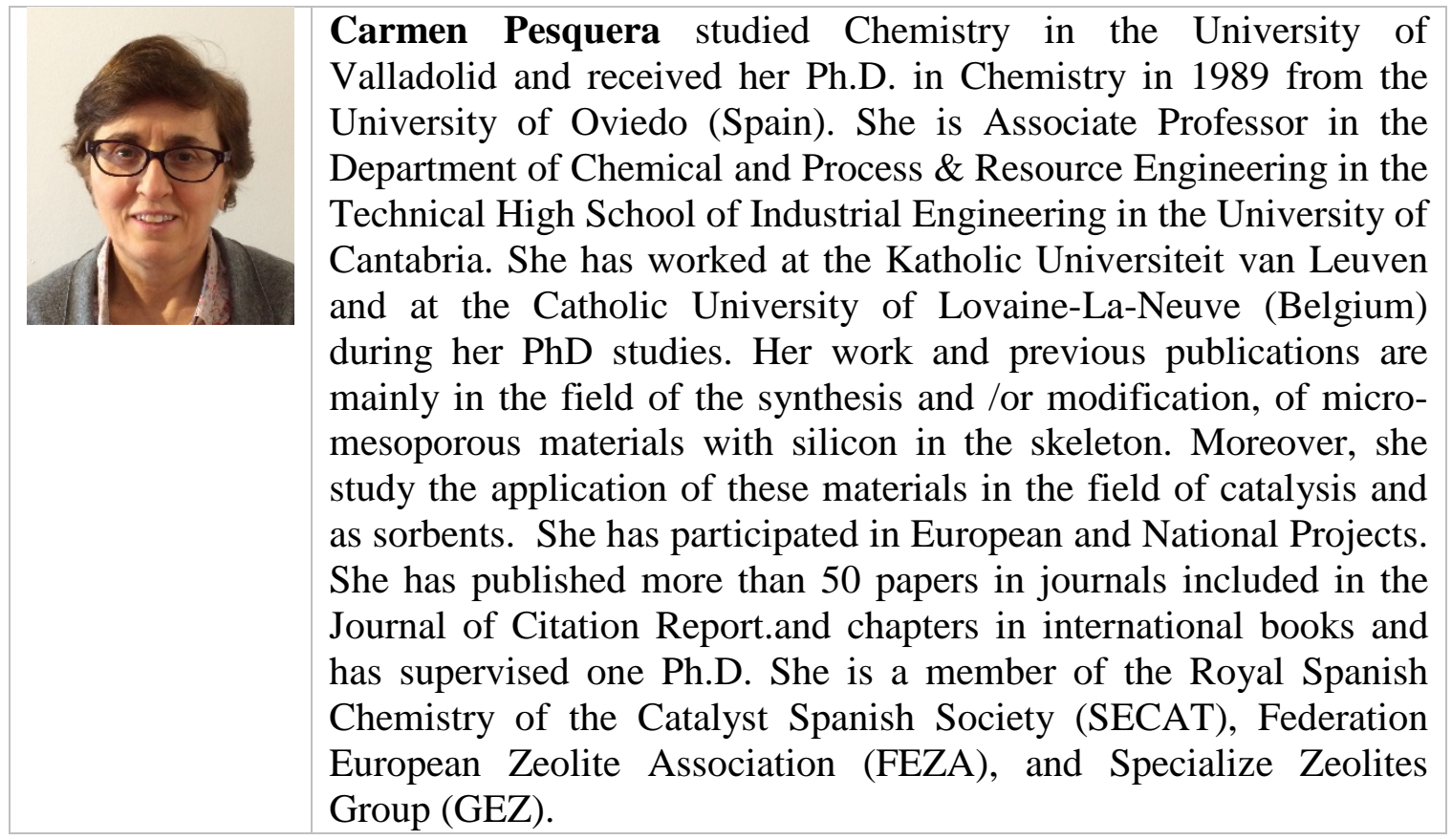

